\title{
SPECIATION AND MORPHOLOGIC EVOLUTION IN THE ORDOVICIAN CONODONT GENUS IAPETOGNATHUS, AN ATYPICAL RAMIFORM- RAMIFORM APPPARATUS STRUCTURE
}

NICOLL ${ }^{*}$, Robert S., Australian Geological Survey, PO Box 378, Canberra, ACT, Australia, 2601; MILLER, James F., Dept. of Geography, Geology, and Planning, Southwest Missouri State University, Springfield, Missouri 65804-0089, U.S.A.; NOWLAN, Godfrey S., Geological Survey of Canada, 3303 33rd Street NW, Calgary, Alberta, Canada T2L 2A7; REPETSKI, John E., U.S. Geological Survey, MS 926A National Center, Reston, Virginia 22092, U.S.A.

The Cambrian-Ordovician boundary conodont genus Iapetognathus Landing appears to be an atypical multielement, likmas type, ramiform-ramiform apparatus. Elements of Iapetognathus have a prominent outer lateral process, and the posterior process is reduced or absent. This morphology clearly distinguishes the genus from other early denticulated conodont genera, such as Eodentatus Nicoll \& Shergold and Cordylodus Pander, whose elements have a well developed posterior process. The interpreted structure of the apparatus appears to be somewhat similar to that of Erraticodon Dzik, except for the lack of a posterior process on constituent elements. The full apparatus components of Iapetognathus have not been differentiated, but at least five element types are now recognized, with the $\mathrm{M}$ and Sa elements not positively isolated.

The genus appears to be biostratigraphically important near the Cambrian-

Ordovician boundary interval and may be useful in defining the base of the Tremadocian Series and thus the Ordovician. Iapetognathus has a worldwide distribution and is now known from Argentina, Antarctica(?), Australia (Queensland), Canada (Alberta, Newfoundland), China (Jilin), Estonia, Kazakhstan, Russia (Siberia), Norway, Sweden, and the U.S.A. (Pennsylvania, Maryland, Virginia, Oklahoma, Texas, New Mexico, Utah, Nevada, Alaska). It has been reported from a variety of environments and is known from both shallow and deep water depositional settings.

Four species of Iapetognathus are now recognized, I. aengensis (Lindström), the type species, I. n. sp. 1 and $I$. n. sp. 2 of Miller, and $I$. n. sp. A of Nowlan \& Nicoll. Miller has a few elements from Utah which may represent a fifth species. I. preaengensis Landing is now considered to be a junior synonym of I. aengensis. 